\title{
Günter Lange 65 Years
}

$\mathrm{G}$ ünter Lange wurde am 26. Juli 1936 in Rostock geboren. Er studierte Maschinenbau, Fachrichtung Wärme- und Verfahrenstechnik und promovierte 1965 an der Technischen Universität Braunschweig bei Wilhelm Hofmann mit dem Thema ,Zusammenhang zwischen Wasserstoffaufnahme und Porosität des Eisens “, ein Thema, das ihn auch heute noch fesselt. 1971 habilitierte er mit einer Arbeit über den Wärmehaushalt beim Strangpressen. Seit 1974 vertritt er als Universitätsprofessor das Gebiet „Angewandte Werkstoffkunde “ an der Alma Mater Brunsvigiensis.

Sein wissenschaftliches Arbeitsgebiet reicht von komplexen Beanspruchungskollektiven und dem daraus resultierenden Versagen von Bauteilen bis $\mathrm{zu}$ aufwendigen metallkundlichen Experimenten zum Nachweis der Versagensmechanismen. Ziel seines Interesses war stets das Verhalten metallischer Werkstoffe bei der Realbeanspruchung von Bauteilen. Im Mittelpunkt stand die Erforschung der Bruchmechanismen und die Erklärung der Brucherscheinungsformen. Für den duktilen Gleitbruch erarbeitete er mit großem experimentellen Geschick eine Gesamtsystematik des Wabenbruches von der mikroskopischen Entstehung bis zur Erklärung aller makroskopischen Bruchtypen. Für den Schwingbruch - den er traditionell immer noch gern als „Dauerbruch“ bezeichnet - hat er wesentlich zum Verständnis des Zusammenhangs zwischen den Lastzyklen und der Auswertbarkeit der Schwingstreifenzahl beigetragen. Über 10 Jahre hat er den Arbeitskreis der Deutschen Gesellschaft für Materialkunde „Fließspannung und Festigkeit" geleitet. Die Ergebnisse seiner Arbeiten sind in zahlreiche Lehrbücher eingegangen und wir verdanken ihm eine klare Vorstellung von vielen Bruchvorgängen und ihre detaillierte Verknüpfung mit sehr unterschiedlichen Beanspruchungskollektiven. Weit mehr als 100 Veröffentlichungen und ca. 350 wissenschaftliche Vorträge haben sichtbare Spuren in unserer „Scientific Community “ hinterlassen. Für dieses Oeuvre erhielt er 1997 von der Deutschen Gesellschaft für Materialkunde die hoch angesehene Tammann-Gedenkmünze.

Derzeit befasst er sich im Rahmen eines Sonderforschungsbereichs mit mehrachsigen Schwingfestigkeits-Untersuchungen. Der wissenschaftliche Reiz liegt in der Verknüpfung der Gesetze der Mechanik mit den Erkenntnissen der Werkstoffkunde. Damit verkörpert er in idealer Weise den Ingenieurwissenschaftler, dem es gelingt, Grundlagenforschung mit Aufgabenstellungen aus der Praxis zu verbinden und in didaktisch so brillanter Weise aufzubereiten, dass er Studenten und Auditorien wissenschaftlicher Kongresse gleichermaßen fesselt. Zwar sagt er gern ,wie soll ich wissen, was ich denke, bevor ich höre, was ich sage “, aber das genaue Gegenteil zeichnet ihn aus. Es ist wohl der Ausdauersport, der ihm das Durchstehvermögen in der Forschung ermöglicht, und es ist sein subtiler Humor, der den Zuhörern gestattet, den Einstieg auch in schwierige Zusammenhänge zu finden.

Günter Lange liebt die Wissenschaft, aber was wäre die „Angewandte Werkstoffkunde" ohne seine besondere Befähigung, bei praktischen Problemfällen und technischen Weiterentwicklungen zielführend Hilfestellung zu leisten?
$\mathrm{G}$ ünter Lange was born on 26 July 1936 in Rostock. He studied mechanical engineering in the field of heat and process technology. In 1965, he wrote his doctoral thesis about the correlation between hydrogen absorption and the porosity of iron at the chair of Wilhelm Hofman at Technische Universität Braunschweig. Even today, he still considers this topic fascinating. In 1971, he wrote his postdoctoral thesis about the heat balance during extrusion to qualify as a university lecturer. Since 1974 he has been University Professor for applied material technology at his alma mater brunsvigiensis. His scientific research comprises complex stress collectives and the failure of components resulting from them as well as subtle metallurgical investigations of failure mechanisms.

His research has focused on the behaviour of metallic materials in the case of real stress of components. The investigation of fracture mechanisms and the explanation of fracture phenomena have been some of the most important aspects. With great experimental skill he developed a complete systematology of dimple fractures for microscopic shear fractures. This systematology includes the microscopic formation of fractures as well as the explanation of all macroscopic types of fracture. As to the fatigue fracture, which he has traditionally called "endurance fracture", he contributed significantly to the understanding of the correlation between load cycles and the analysis of the number of fatigue striations. For more than 10 years he had led the "Yield Stress and Strength" study-group of the German Material Society (Deutsche Gesellschaft für Materialkunde). The results of his investigations had influence on a wide range of instructional material and he provided a clear idea of many fracture processes as well as a detailed connection of these processes to different stress collectives.

More than 100 publications and more than 350 scientific lectures have left visible traces in our scientific community. For his merits, he was awarded the highly respected Tammann commemorative coin by the German Material Society in 1997.

Recently, he has researched into the complex field of multiaxial fatigue tests and has significantly extended our knowledge about yield planes in the field of tensile stresses and shear stresses. Here, the scientific interest has above all consisted in the connection between material aspects and the laws of mechanics.

Thus, in an ideal way, he personifies the engineering scientist who manages to combine basic research with practical problems and who presents them in such a didactically brilliant way that he holds the attention of students as well as of the audience of scientific conventions. Even though he frequently says "how am I to know what I'm thinking before I hear what I'm saying" it is the exact opposite which characterises him. It must be his stamina training that provides him with staying power in his research and it is his subtile humour that enables his listeners to understand even complex subjects.

Günter Lange loves science, but what would applied material technology be without his special ability to give efficient assistance in the case of practical problems and technical developments? 
Er stapelt gern tief, indem er seine akademische Laufbahn als „gehobene Schlosserlehre“ bezeichnet, die ihm das Rüstzeug für die systematische Schadensanalyse gibt. Ich kenne niemanden, der sich durch unzählige Schadensuntersuchungen einen so soliden Kenntnisstand erworben hat und diesen mit einem derart untrüglichen Gespür für technische Zusammenhänge verknüpft. Dabei akzeptiert er die Problemlösung vor sich selbst erst, wenn der schadenverursachende Mechanismus exakt nachgewiesen ist. Man kann ihn ohne Übertreibung als den herausragenden Schadenskundler unserer Zeit bezeichnen. Besondere Schwerpunkte haben sich auf den Gebieten der medizinischen Implantate sowie der Flugzeuge und auf seinem Lieblingsgebiet herauskristallisiert, dem wasserstoffinduzierten Bruch mit all der Hinterhältigkeit, zu der die leblose Materie in der Lage ist.

Zur Klärung von Schadens-Großereignissen wird er häufig hinzugezogen, sei es eine Rückruf-Aktion der Automobilindustrie oder sei es der dramatische Radreifenbruch von Eschede oder die mysteriösen Umstände des Estonia-Untergangs. Seit rd. 40 Jahren ist er Gutachter für das Luftfahrt-Bundesamt und hat mit der Untersuchung von mehr als 300 Flugunfällen entscheidend zu ihrer Klärung beigetragen. Dafür wurde ihm 1991 das Bundesverdienstkreuz verliehen.

1982 hat er das legendäre Ermatingen-Seminar „Systematische Beurteilung technischer Schadensfälle “ in der Schweiz begründet, das - stets überbucht - in diesem Jahr zum 22. Mal aktualisiert stattfindet und als einwöchiger Intensivkurs inzwischen von mehr als 700 Teilnehmern besucht wurde. Inzwischen findet dieses Seminar im Wechselspiel mit dem mehr auf Labortätigkeit ausgerichteten „VDI-Hochschulpraktikum Schadensanalyse“ statt, in dessen Leitung er ebenfalls involviert ist. Hier ergänzen sich unsere Fachverbände in vorbildlicher Weise; wen wundert's, schließlich wirken in ihnen die gleichen Akteure. Günter Lange hat sich um viele Arbeitskreise verdient gemacht, seine messerscharfe Logik, gepaart mit druckreifer Formulierung, ist in Regelwerke, Leitfäden und Systematiken eingegangen, genannt sei das Nachschlagewerk „Erscheinungsformen von Rissen und Brüchen metallischer Werkstoffe".

Für 7 Jahre engagierte Leitung des VDI-AK Schadenanalyse, wozu auch die Veranstaltung der VDI-Jahrestagung Schadensanalyse auf der Festung Marienberg in Würzburg gehört, wurde ihm der Ehrenvorsitz verliehen. Für sein Gesamt-Engagement auf dem Gebiet der Werkstofftechnik wurde ihm im Jahr 2000 die besondere Auszeichnung der Karl-Wellinger-Medaille zuteil.

Wer jemals einen seiner lebhaften, mit feinem Humor gewürzten Vorträge gehört hat, wie mit exzellentem Bildmaterial komplexe Sachverhalte erschlossen werden, versteht die zahlreichen Einladungen von China bis Brasilien und seinen Erfolg bei den Studenten.

Seine integere Persönlichkeit, seine Warmherzigkeit und Bescheidenheit, gepaart mit Objektivität und Kompetenz, verschaffen ihm Anerkennung und persönlich Wertschätzung bei seinen Hochschulkollegen, Mitarbeitern und Studenten sowie bei allen Fachkollegen aus der Industrie und den Fachverbänden.

Dem herausragenden Wissenschaftler und Repräsentanten seines Faches, Günter Lange, dessen Verdienste hohe Anerkennung gefunden haben, gratulieren seine Kollegen und Weggefährten. Wir erwarten noch viel von ihm und freuen uns auf jede Begegnung.
He likes to be rather modest about his academic career by referring to it as a sophisticated metalworking apprenticeship which has provided him with the qualifications for systematic failure analysis. I don't know anybody else who has acquired such profound knowledge and an almost infallible intuition in this field through numerous investigations. He only accepts the solution to a problem if the mechanism which caused the damage has been exactly identified. Without exaggeration, he can be called the outstanding failure analyst of our time. He has especially focused on the field of medical implants, aircraft and his favourite field, hydrogen-induced fractures with all the underhandedness of which inanimate materials is capable.

He has often been asked to assist in analysing the cause of major failures or disasters, be it the recall of products in the automobile industry, the dramatic wheel fracture that led to the railway disaster of Eschede or the mysterious circumstances of the sinking of the Estonia. For approximately 40 years he has been an appraiser at the Federal Aviation Authority and he has considerably contributed to the solution of more than 300 air disasters. Therefore, he was awarded the order of the Federal Republic of Germany in 1991.

In 1982, he founded the legendary and ever-overbooked seminar on the "Systematic Analysis of Technical Failures" in Ermatingen, Switzerland. This seven-days intensive course has had more than 700 participants so far and will this year be held for the $22^{\text {nd }}$ time. Alternating with this seminar, the university experience scheme by VDI on failure analysis is held, in whose coordination Günter Lange is also involved. Our professional associations perfectly supplement each other. Since it is the same people that are involved in the two associations this comes as no surprise. Günter Lange has contributed significantly to the work of many study-groups. His sharp logic and his perfect formulation are to be found in basic textbooks and taxonomies, such as the encyclopaedia on "The Appearance of Cracks and Fractures in Metallic Materials".

For his commitment during 7 years as chairman of the "Failure Analysis' study-group of VDI, to which the annual 'Failure Analysis' conference of VDI being held at Marienberg Castle, Würzburg, belongs as well, he was appointed honorary chairman. In 2000, he was awarded the Karl-Wellinger medal for his overall commitment in the field of materials technology.

Whoever has listened to one of his lively and humorous lectures and has experienced how complex subject matters are explained by means of excellent illustrations will understand the numerous invitations from China to Brazil and his success with students.

His fellow professors, colleagues and students, as well as his colleagues from professional associations and industry appreciate his personality of integrity, his warm-heartedness and modesty which is combined with objectivity and competence.

His colleagues and fellow-travellers wish to congratulate Günter Lange, the outstanding scientist and representative of his academic field, whose contributions have been widely respected. We still expect more contributions of him and are looking forward to every meeting.

Michael Pohl, Bochum 